\title{
Discurso Presidencial: Ciência, Pessoas e Justiça. Uma Visão da Sociedade Panamericana de Trauma
}

\author{
Sandro Rizoli
}

\section{INTRODUÇÃO}

É uma honra apresentar o discurso presidencial da Sociedade Panamericana de Traumatologia (SPT) no XXXI Congresso Panamericano de Trauma na bela cidade de Cartagena na Colômbia. Nossos agradecimentos à cidade pela calorosa recepção e à Asociacon Colombiana Cirurgia (ACC) na pessoa de seu presidente Dr. Quintero. Também quero agradecer ao Dr. Carlos Ordonez, liaison e responsável por reunir as duas sociedades.

A Colômbia já fez muitos dos melhores congressos da SPT recentemente. Lembro-me vivamente do Congresso de 2012 em Medellín com o Dr. Carlos Morales. E agora, em 2018, temos o privilégio de um congresso combinado da ACC e seu XLIV Congresso Nacional. Meus repetidos e sinceros agradecimentos pela hospitalidade.

Eu gostaria muito de parabenizar a Colômbia por um excelente desempenho na recente Copa do Mundo da FIFA na Rússia, mas infelizmente a Inglaterra atrapalhou - e nos pênaltis. O único consolo que posso oferecer é que meu próprio país de origem, o Brasil, não fez nada melhor, apesar das tentativas teatrais de Neymar de cair e pedir penalidades. Quanto ao país onde tenho residido nos últimos 25 anos (o Canadá), este nem sequer se classificou para a copa da Rússia (de novo).

\section{O Dilema da Minha Filha es avanços na CiênCia do Trauma}

Deixe-me começar por lhe apresentar minha família - minha esposa e meu filho mais novo estão aqui em Cartagena (Fig. 1). Apesar de todos os meus esforços, apenas um dos meus 5 filhos decidiu ir para a Faculdade de Medicina, minha única filha. Os quatro irmãos escolheram outras opções para a vida professional deles. A pergunta que fiz a mim mesmo é qual especialidade eu aconselharia minha filha a escolher se ela alguma vez me perguntasse, (o que sei que ela não perguntará). Sem hesitação, eu a aconselharia a ser cirurgiã. Essa foi a escolha que fiz e, sem dúvida, foi a melhor escolha. Eu considero a cirurgia como uma parte intrínseca de quem eu sou. Muitos de vocês concordarão que "ser cirurgião é o que eu sou e não o que faço". Até hoje minha esposa pode dizer se eu operei ou fiz trabalho administrativo, apenas pelo meu nível de felicidade quando chego em casa. Minha satisfação não é a mesma quando faço apenas trabalho de escritório (fico rabugento). Em uma análise recente da minha apólice de seguro de saúde, os avaliadores concluíram que vou continuar operando até meu último dia. Ser cirurgião é (e sempre foi para mim) a melhor opção. Por outro lado, devo admitir que não é fácil ser cirurgião. É exigente no meu tempo, eu ainda trabalho a noite e fins de semana e muitas vezes não passo tanto tempo com a família quanto eu gostaria. Talvez minha filha queira ter uma família e filhos. Além disso, a geração dela não fará tantas cirurgias abertas como fazemos hoje. Se não for cirurgia do trauma, que outra especialidade eu poderia sugerir?
Professor Titular de Cirurgia da Universidade de Toronto, Ex-Presidente da Sociedade Panamericana de Trauma, Diretor Médico de Trauma, Hospital Geral de Hamad, Doha, Qatar

Endereço para correspondência: Hamad General Hospital, Doha, Catar, e-mail: srizoli@hamad.qa

How to cite this article: Sandro Rizoli. Discurso Presidencial: Ciência, Pessoas e Justiça. Uma Visão da Sociedade Panamericana de Trauma. Panam J Trauma Crit Care Emerg Surg 2019;8(1):12-18.

\section{Source of support: Nil}

Conflict of interest: None

Talveza Radiologia Intervencionista (IR), que é uma especialidade em franco crescimento, e não é tão exigente com tempo como a cirurgia do trauma. Radiologistas intervencionistas são cirurgiões que operam com cateteres e "coils". No St Michael's Hospital (SMH), em Toronto, o IR emboliza e cuida de mais aneurismas cerebrais do que os neurocirurgiões. Não raro, um paciente traumatizado tem a ressuscitação (corretamente ou não) prolongada para permitir que os colegas da IR embolizem sangramentos de fraturas pélvicas. Os resultados com embolização são melhores do os resultados de uma cirúrgia aberta. O sonho de muitos centros de traumatologia é ter salas de operação híbridas onde cirurgiões e anestesistas trabalham juntos para manter o paciente vivo enquanto o radiologista é quem para o sangramento. A desvantagem da minha filha escolher o IR é que ela nunca fará uma cirurgia aberta.

O Dr. Scalea, do Shock Trauma em Baltimore, tem um programa que treina cirurgiões para fazer os procedimentos de IR. Até recentemente, eu pensava que o tratamento usando técnicas de reparo endovascular (conhecidas como endovascular trauma management ou EVTM) era o futuro do trauma. Então eu ouvi o Dr. Holcomb (orador principal deste congresso) no congresso de EVTM em Houston recentement e percebi que EVT não é o futuro, mas o presente. De fato, pode-se encontrar manuscritos do Dr. Ordonez relatando dezenas de pacientes tratados com balões de oclusão aórtica endovascular (REBOA) feitos em Cali na Colombia, um equipamento que acabamos de comprar para Toronto. Recentemente, operei um paciente com dissecção traumática da aorta que se estendia para a artéria mesentérica superior (AMS). Depois que minha equipe fez a laparotomia aberta para confirmar que não havia intestino infartado, os colegas d ciurgia vascular esperaram até eu fechar a laparotomia e depois via endovascular, eles uaram um "stent" via endovascular para reparar a aorta e a AMS.

Existem também inúmeras tecnologias emergentes (e fascinantes) no suporte de órgãos em Cuidados Críticos. Talvez eu deva sugerir à minha filha que escolha fazer Terapia Intensiva e trabalhe no campo de suporte de órgãos. Cateteres com bombas, como dispositivos de suporte ventricular temporário percutâneo para disfunção cardíaca traumática. Esses cateteres com bomba estão sendo estudados em situações de parada cardíaca

(-) The Author(s). 2019 Open Access This article is distributed under the terms of the Creative Commons Attribution 4.0International License (https://creativecommons. org/licenses/by-nc/4.0/), which permits unrestricted use, distribution, and non-commercial reproduction in any medium, provided you give appropriate credit to the original author(s) and the source, provide a link to the Creative Commons license, and indicate if changes were made. The Creative Commons Public Domain Dedication waiver (http://creativecommons.org/publicdomain/zero/1.0/) applies to the data made available in this article, unless otherwise stated. 


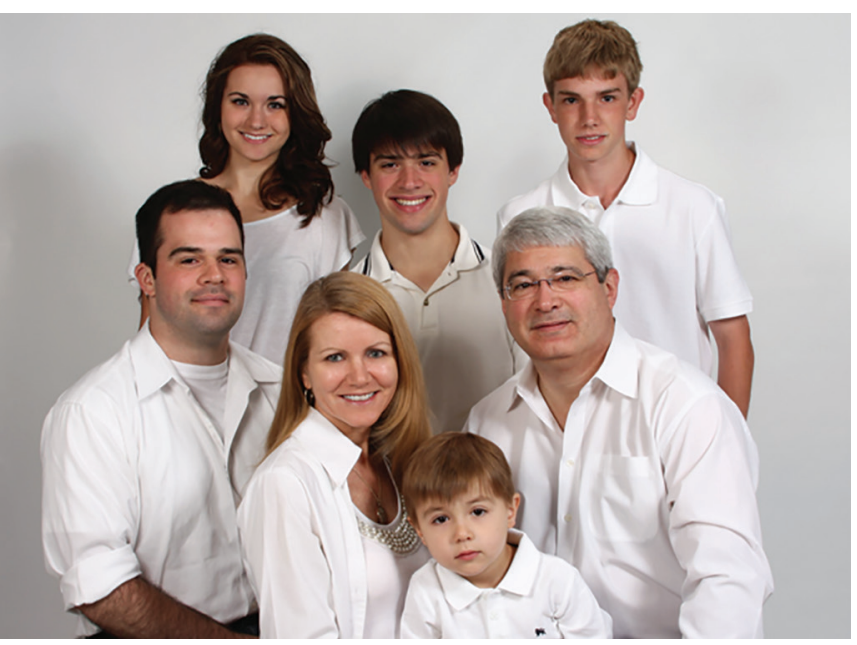

Fig. 1: Família Pacher-Rizoli

pós-trauma. Muitas dos participantes deste congresso aqui hoje, têm acesso rotineiro à oxigenação por membrana extracorpórea (ECMO) para suporte cardíaco e respiratório. Além de avançados equipamentos de monitorização multimodal para o tratamento de pacientes com lesão cerebral traumática. Chestnut et al. 2012 estudaram na Bolívia e no Equador (1) as melhores maneiras e monitorizar pressão intracraniana (PIC), muitas outras tecnologias continuam ser apesentada para o suporte da vida dos pacientes traumatizados. É simplesmente impressionante.

Ao rever todas essas opções para responder uma pergunta que minha filha não me fez, percebi o quanto a "ciência" do trauma evoluiu. Enquanto muitas coisas permanecem inalteradas, o trauma é uma especialidade em evolução, complexa e fascinante que requer treinamento, dedicação total e tempo. Os cirurgiões de trauma ao redor do mundo incorporaram (e com felicidade) a cirurgia de urgência não-traumática (acute care sugery) na sua prática, estão se tornando mais proficientes em cirurgia minimamente invasiva e utilizam tecnologias avançadas de imagem e IR. Em comparação com o treinamento em traumas que fiz há 25 anos atrás, os fellowships atuais oferecem treinamento em IR, em EVTM avançado alem de cuidados intensivos, apoio de órgãos / vida e em uma cacofonia de monitores. A ciência do trauma evoluiu enormemente e a mudanças foram rapidamente adaptadas à prática diária. As mudanças em IR, EVTM, monitores multimodais, etc. não são para o futuro, mas são padrões atuais de atendimento (para muitos de nós). Estamos vivendo (e praticando) em um novo mundo.

\section{O Avanço Mais Importante = Pessoas}

Desde o começo, trauma foi caracterizado pelo trabalho em equipe. Sempre me impressiona o fato de que a maioria das apresentações da história do trauma é feita usando fotos de muitas pessoas, enfermeiras, residentes, registradores, educadores e tantos outros especialistas. Poucas fotos têm uma única pessoa, na maioria das vezes é uma foto de grupo.

Cada paciente traumatizado passa por um continuum de cuidados qu começa antes mesmo do evento traumático em si (prevenção de lesões). Depois que o trauma acontce, o atendimento do paciente passa pelas equipes pré-hospitalares, de ressuscitação na sala de trauma, equipe no centro cirúrgico, cuidados intensivos (UTI), enfermaria e depois reabilitação. Existe uma equipe para cada etapa, que se integra no continuum do atendimento. É o "sistema de trauma" onde diferentes instituições integram o atendimento

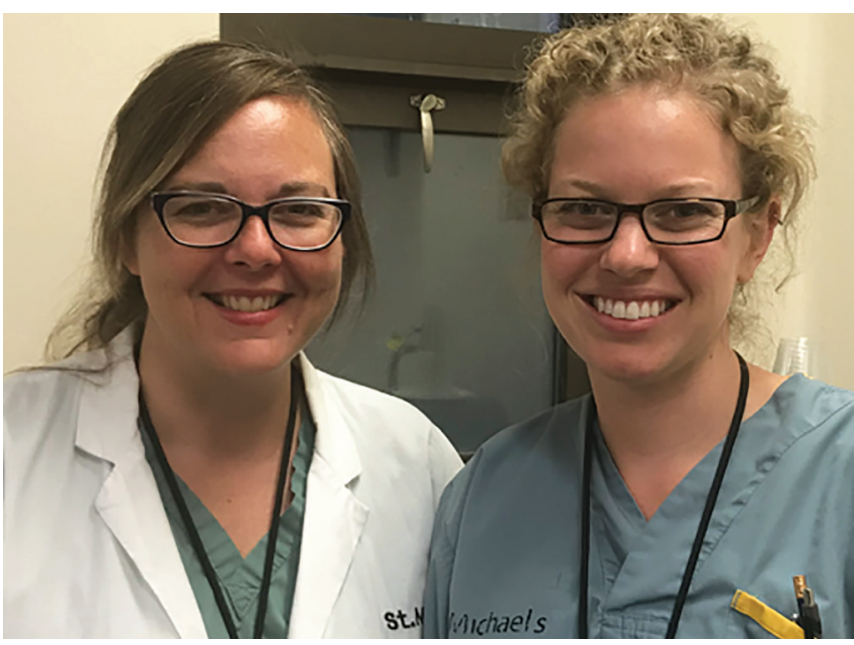

Fig. 2: Kirsty Nixon e Heather Perry, nurse practitioners do Hospital St. Michael's

seguidos das equipes na sala de ressuscitação, no centro cirúrgico, na UTI, na enfermaria, na reabilitação, etc., etc.

Deixe-me apresentar Kirsty Nixon e Heather Perry (Fig. 2), os rostos de outro avanço extraordinário no atendimento ao paciente traumatizado. Kirsty e Heather são enfermeiras "practitioner" (ou $\mathrm{NP}$ ) no meu hospital (SMH). Elas têm licenças independentes que seguem regras que determinam o que elas podem fazer, conhecidas como "scope of practice". Elas passam visita em todos os pacientes na enfermaria de trauma diariamente, prescrevem, pedem testes laboratoriais e radiológicos, dão alta, escrevem receitas e organizam o acompanhamento pós-alta, entre muitas outras coisas. Elas também tocam o ambulatório de traumas, onde começam a visita perguntando "como você está em casa?" Neste ambulatório, os pacientes são rastreados (screened) para transtornos de humor, estresse pós-traumático, traumatismo craniano, dor e abuso de substâncias. Elas fazem tudo e mais. A adição de NP à equipe de trauma melhorou a qualidade dos cuidados e o outcome dos pacientes. Exemplo do impacto das NP é que cerca de $80 \%$ dos nossos pacientes ambulatoriais costumavam receber uma receita de narcóticos para o controle da dor. Hoje como as NPs rastreiam para distúrbios que não são tratados com opioides (como transtornos do humor, PTSD, etc.), descobrimos que a dor pode ser apenas uma expressão de outros desajustes causado pelo trauma. Hoje, apenas $10 \%$ dos pacientes traumatiados atendidos no ambulatório do $\mathrm{SMH}$ recebem uma receita para opióides. O cuidado que oferecemos aos nossos pacientes melhorou, e muito. Por causa das mudanças implementadas pelas NPS, outros distúrbios são diagnosticados e tratados, muitos dos quais não estávamos diagnosticando antes. Outras instituições como o Shock Trauma em Baltimore (também sob a liderança do Dr. Scalea) oferecem programas de residência / fellowship para NPs em trauma (se voce estiver interessado(a)).

Kirsty e Heather são exemplos do crescente papel dos profissionais não-cirurgiões no atendimento ao trauma. No meu hospital, as NPs trabalham com os cirurgiões, residentes e alunos e são membros essenciais do grupo. É importante mencionar outros profissionais que auxiliam na repatriação e alta dos pacientes, nutricionistas, terapeutas ocupacionais, fisioterapeutas, capelães e assistentes sociais. Diferentes profissionais são parte essencial do cuidado (e se complementam), em benefício dos pacientes.

Exemplos de outros profissionais-chave de qualquer programa de trauma são aqueles envolvidos nos programas de prevenção 
de lesões, pesquisa, registro e programas de melhoria de qualidade (QI). Nossa gerente de QI no SMH, Amanda McFarlan, junto com uma sobrevivente de trauma, Margaret Harvey, criou e administrou a "rede de sobreviventes do trauma". A rede My Best (além de sobreviver - prosperar) oferece apoio aos sobreviventes, mesmo anos após a alta hospitalar. $\mathrm{O}$ atendimento dos pacientes traumatizados não termina no momento em que eles saem do hospital. Na verdade, a maioria leva anos (alguns podem levar a vida inteira) para se reajustarem após um grande evento traumático. Gostamos de pensar que os profissionais do trauma cuidam do paciente "por inteiro", o que é verdade, e a razão desta abordagem global vem do fato de a vida inteira do paciente muda após uma lesão grave.

"Para educar uma criança precisa uma aldeia", o mesmo pode ser dito sobre cuidar de um único paciente traumatizado, requer uma "aldeia" de muitos profissionais. Cirurgiões assim como enfermeiros, fisiatras, etc. fazem parte de uma equipe. A importância e o papel de diferentes profissionais no atendimento ao trauma está evoluindo e crescendo. Cada profissional tem um "niche" onde ele / ela é o(a) mais qualificado(a) para fazer. Na minha opinião, as "pessoas" (profissionais de trauma) sempre tiveram um papel maior na melhoria do atendimento ao traumatizado do que a ciência.

O objetivo de tratar os pacientes com trauma é oferecer aos pacientes o melhor resultado (outcome) possível. Os pacientes são a razão de tudo que fazemos. E estamos apenas aprendendo o quão importante cada passo no continuum do cuidado do paciente, determina o resultado. Cada passo e as transições entre cada passo contam, e muito.

\section{Podem a Violência no Trânsito e a Violência Armada Acabar? Argumentos EM JUSTIÇA}

Enquanto o atendimento ao trauma evoluiu, tornando-se mais centrado no paciente e praticado por muitos profissionais, nosso mundo político não mudou muito. Todos os dias continuamos a ouvir notícias de violência. Os recentes incluem os países da OTAN pressionados a gastar mais em armamentos, militarização do espaço, número crescente de conflitos armados (guerras), fechamento de fronteiras, muros fronteiriços e refugiados. A própria Colômbia experimentou recentemente o ingresso de cerca de 1,5 milhão de deslocados deixando a vizinha Venezuela.

A história recente das Américas tem sido marcada pela violência. Na Colômbia, o conflito com a guerrilha resultou em 260.000 mortes, a Venezuela e a Nicarágua estão enfrentando conflitos internos, tiroteios em massa nos Estados Unidos, mais de 60.00 homicídios no Rio de Janeiro no ano passado e mesmo em minha cidade natal de Toronto vimos recentemente uma onda de incidentes violentos. O Canadá ficou chocado quando uma van subiu numa calçada em abril passado, em um ataque terrorista que matou 10 pessoas. Apenas duas semanas atrás, uma pessoa disparou indiscriminadamente num rua alguns quilômetros de minha casa, ferindo 13 pessoas, notícias de violência em Fredericton (New Brunswick), além do atentado de 2008 no voo da Air India, ainda estão em nossas mentes. Esses eventos estão acontecendo (literalmente) muito perto de casa.

Os pacientes lesionados sucumbem principalmente por duas causas: o trânsito e a violência armada, e ambos são evitáveis. Confesso que prestei muito mais atenção a assistência hospitalar do que a prevenção, mas a possibilidade de que a violência pode ser erradicada, me fez repensar estas prioridades - e é muito atraente. Talvez impossível que isto aconteça durante a minha vida? Eu estou pensando que talvez seja possível.

Muitos de vocês devem conhecer o conceito de "Vision Zero". É uma iniciativa para acabar com as mortes por eventos de trânsito. Eu gosto de pensar que a violência armada poderia ser adicionada a esse objetivo. No último século, cidades foram construídas para os carros. A proposta é mudar e fazer as cidades para a vida humana. Imediatamente, penso que tais idéias só serviriam para países europeus e alguns países socialistas. Mas para minha surpresa, aprendi que o "Vision Zero" foi adotado em Nova York. Recentemente, o prefeito de Nova York anunciou que nos últimos 4 anos, NYC experimentou uma queda de $50 \%$ nas mortes de pedestres, mas instituiu medidas simples que consideram a vida das pessoas mais importante do que os carros. Confesso que não ouvi nada sobre Nova Yorke e o Vision Zero nas notícias.

Tratamos pacientes que sofrem de uma doença, trauma, que é causado principalmente pelo trânsito e violência armada, e ambos são totalmente evitáveis. É possível erradicá-los. Nenhuma morte por uma causa evitável pode ser aceitável. Em nome de nossos pacientes, devemos fazer todo o possível para acabar com trauma.

\section{A Sociedade Panamericana de Trauma (SPT)}

A história e o passado do SPT foram mencionados pelo Dr. Scalea na palestra de abertura deste congresso, enquanto a história completa pode ser lida no manuscrito dos Drs Ivatury e Aboutanos no Panamerican Journal of Trauma (PAJTCCES) $(2,3)$. O SPT é uma sociedade fundada e nutrida por muitos que estão presentes aqui hoje, incluindo o Dr. Aurelio Rodrigues, o Dr. Barba e o Dr. Olguin. Como o Dr. Ivatury mencionou uma vez, o SPT foi "construído no ombro de gigantes".

Hoje, o SPT está passando por um momento de renovação e mudança. A Sociedade existe para reunir todos os profissionais de trauma, do continente inteiro (falando 4 idiomas: espanhol, português, inglês e francês), para trabalhar em conjunto para melhorar o atendimento ao paciente lesionado. As mudanças na SPT podem ser testemunhadas na reestruturação do nosso congresso anual. O Congresso de 2018 é uma proposta diferente, desde a forma como foi planejada com o ACC até a forma como as palestras foram ministradas (conferências de consenso com participação aberta em vez de palestras). Hoje temos o privilégio de viver essa transformação na bela cidade de Cartagena, que confesso que foi uma isca para atrair os participantes.

A Sociedade também está empenhada em aumentar a participação de mulheres, profissionais não-cirurgiões, dar oportunidade e nutrir líderes emergentes e aumentar as colaborações multi nacionais, aumentando as oportunidades de treinamento no exterior, intercâmbio de estagiários, teleconferências multinacionais, orientação sobre como escrever manuscritos e as ligas de trauma do estudante de medicina criadas pelos Drs. Mantovani e Gustavo Fraga.

A transformação do Jornal Panamericano de Trauma, Cuidados Críticos e Cirurgia de Emergência (PAJTCCES) é um excelente exemplo das recentes mudanças na Sociedade e da liderança decisiva do Dr. Ivatury. A expectativa é que o periódico seja indexado no Pubmed em breve e continue a crescer como veículo para a produção científica das Américas.

Outras grandes iniciativas da SPT incluem os inúmeros e bem sucedidos cursos oferecidos pela Sociedade. Os cursos estão entre 
os melhores produtos gerados e oferecidos pela SPT. A Sociedade também patrocina estudos multi-institucionais para estimular colaborações entre diferentes países e instituições e tirar proveito de grandes qualidades da América Latina: o volume de pacientes e o atendimento excepcional ao traumatizado. "Fresh out of the oven" é a nova edição do livro da SPT "Trauma", uma das principais publicações da nossa Sociedade. O Dr. Aurelio Rodriguez é o principal editor e doutores. Drs Ferrada, Ottolino, Aboutanos, Garcia, Lorenzo, Duschene, Pereira e Parreira são editores associados. Finalmente, quero estender minhas calorosas boas-vindas ao novo Presidente da SPT o Dr. Felipe Vega do México e à Secretária Executiva Dra Paula Ferrada. Também quero expressar grandes expectativas para o Congresso de 2019 em La Serena, no Chile.

\section{Conclusões}

Espero ter conseguido transmitir 3 mensagens. Primeiro que a cirurgia do trauma passou por tremendas mudanças nos últimos anos. Grandes avanços científicos e tecnológicos foram trazidos para nossas atividades diárias no cuidado do traumatizado. EVTM, ECMO, suporte a órgãos e monitoramento com multiplas são hoje o padrão no atendimento, enquanto cirurgiões de trauma agora estão treinando em radiologia intervencionista (IR) e cirurgia de urgência (acute care surgery). Apesar das mudanças trazidas pelos avanços da ciência, a prática do trauma mudou muito mais devido aos diferentes profissionais não-cirurgiões que cada vez mais tem um papel essencial de um prática complexa e em constante mudança. Os pacientes são os beneficiários de todas as mudanças no processo de atendimento.
Segundo vem o reconhecimento de que o trauma é uma doença prevenível e é possível acabar com as suas principais causas (trânsito e arma de fogo). Ninguém deve morrer ou sofrer por causa da violência no trânsito ou violência armada.

Uma das melhores experiências da minha vida foi ser o presidente da Sociedade Panamericana de Trauma. O principal trunfo da SPT, como em qualquer sistema de trauma, são as pessoas que temos o privilégio de ter como membros, vindas de todo o continente, e que estão avançando os limites do conhecimento e do cuidado. Membros que compartilham uma visão comum: o melhor atendimento ao paciente traumatizado.

Voltando à pergunta fictícia que fiz no começo deste discurso: se minha filha me perguntasse qual especialidade escolher, eu teria duas sugestões: 1. Seja uma cirurgiã de trauma. Mas mais importante inda, eu a aconselharia a: 2. Ser um membro da Sociedade Panamericana de Trauma. Obrigado à Asociacion Colombiana de Cirurgia e a Cartagena por sua hospitalidade, e a cada membro do SPT por construir esta Sociedade. Muchisimas gracias.

\section{REFERÊNCIAS}

1. Chesnut RM, Temkin N, et al. A trial of intracranial-pressure monitoring in traumatic brain injury. N Engl J Med 2012 Dec 27;367(26):2471-2481. DOI: 10.1056/NEJMoa1207363.

2. Ivatury RR, Aboutanos M. Review article Panamerican Trauma Society: the first three decades. Panamerican J Trauma Crit Care Emerg Surg 2017 May-Aug;6(2):90-123.

3. Ivatury RR, Aboutanos M. Panamerican Trauma Society: the first three decades. J Trauma Acute Care Surg. 2017 May;82(5):966-973. DOI: 10.1097/TA.0000000000001393. 


\title{
Science, People, and Justice. Vision of the Panamerican Trauma Society
}

\author{
Sandro Rizoli
}

\section{INTRODUCTION}

It is an honor to give the Panamerican Trauma Society (PTS) Presidential Address at the XXXI Panamerican Congress of Trauma in beautiful Cartagena, Colombia. Our thanks to the city for the warm welcome and to the Asociacon Colombiana Cirurgia (ACC) in the person of its President Dr Quintero. I also want to thank Dr Carlos Ordonez, who was responsible for bringing both societies together.

Colombia has hosted many of the best PTS Congresses in the near past. I vividly remember the 2012 Congress in Medellin with Dr Carlos Morales. And now in 2018, we have the privilege of a combined Congress with ACC and the XLIV National Congress. My repeated thanks and sincere "agradecimientos por la hospitalidad".

I was hoping to congratulate Colombia for an outstanding performance in the recent FIFA World Soccer Cup in Russia, but sadly England got on the way-and on penalties. The only consolation I can offer is that my own home country, Brazil, did not do any better, despite Neymar theatrical attempts to fall and ask for penalties. Moreover, my home country for the last 25 years, Canada, did not even make to the world cup (again).

\section{My Daughter's Dilemma AND the Advances in Trauma Science}

Let me start by introducing you my family - my wife and youngest son are here in Cartagena (Fig. 1). Despite all my efforts, only one of my five children decided to go to Medical School, my only girl. The four brothers had other career choices. The question I made myself, is what specialty I would advise my daughter to choose if she were ever to ask me, which she will not. Without hesitation, I would advise her to be a surgeon. That was the choice I made, and without doubt the best choice. By far. I see surgery as an intrinsic part of who I am. Many of you will agree that "being a surgeon is what I am and not what I do". To this day, my wife can guess when I operated or did paper work, just by my level of happiness when I get home, which is not the same when I only do office work (grouchy). In a recent review of my health insurance policy, the evaluators concluded that I will continue to operate until my last day. Being a surgeon is for me the best option. On the contrary, I must admit that it is not easy to be a surgeon. It is demanding on your time, I still work nights and weekends and often do not spend as much time with family as I would like to. May be my daughter will want to have a family and children. Furthermore, her generation will not do as many open surgeries as we do today. If not trauma surgery, what other specialty could I suggest?

May be interventional radiology (IR), which is a growing specialty that may not be as demanding on her time as trauma surgery. Interventional radiologists are surgeons that operate with catheters and coils. At St Michael's Hospital (SMH) in Toronto, IR embolizes/manages more brain aneurysms than the neurosurgeons. Not infrequently an injured patient has the resuscitative efforts (correctly or not) extended to allow the IR colleagues to embolize pelvic fractures. Results are better for those that are embolized than undergo open surgical hemostasis. The dream of many trauma centers is to have hybrid operating rooms where surgeons and anesthetists work together to maintain the patient alive
University of Toronto; Panamerican Trauma Society; Hamad General Hospital, Doha, Qatar

Corresponding Author: Sandro Rizoli, Hamad General Hospital, Doha, Qatar, e-mail: srizoli@hamad.qa

How to cite this article: Rizoli S. Presidential Address: Science, People, and Justice. Vision of the Panamerican Trauma Society. Panam JTrauma Crit Care Emerg Surg 2019;8(1):12-18.

\section{Source of support: Nil}

\section{Conflict of interest: None}

while IR stops the bleeding. The downside of my daughter choosing IR is that she will never do open surgery.

Dr Scalea at Shock Trauma in Baltimore has a fellowship programs that trains surgeons to perform IR procedures. Until recently, I thought IR and endovascular trauma management (EVTM) was the future of trauma. Then I attended Dr Holcomb (key speaker of the congress) EVTM meeting in Houston and realized it is not the future, but the present. In fact, one can find manuscripts by Dr Ordonez reporting dozens of patients treated with endovascular aortic occlusion balloons (REBOA) in Cali-Colombia, an equipment we just started utilizing in Toronto. Recently I operated a patient with traumatic dissection of the aorta extending into the superior mesenteric artery (SMA). After my team did an open laparotomy to confirm there was no infarcted bowel, the vascular colleagues waited until I closed the laparotomy and then via endovascular, they stented and repaired the aorta and SMA.

There are also numerous emerging (and fascinating) technologies in organ support for critical care settings. Maybe, I should suggest my daughter to choose critical care and the expanding field of organ support. Catheters with pumps such as percutaneous temporary ventricular support devices for traumatic cardiac dysfunction. These catheters with pump are even being studied for post/near cardiac arrest situations. Many of the attendees here today have routine access to extracorporeal membrane oxygenation (ECMO) for both cardiac and respiratory support. Furthermore, the advances in managing patients with traumatic brain injury include multimodal monitorization. Chestnut et al. trial in Bolivia and Ecuador (1) on intra cranial monitor vs $C T$ points to how common intracranial pressure (ICP) monitors have become ubiquitous as well as brain tissue monitors and many other technologies that support the life of the injured patients. It is simply impressive.

While reviewing all these options to address a question my daughter has not asked me, I realized how much the "science" of trauma has evolved. While many things remain unchanged, trauma is an evolving, complex, and fascinating specialty that requires training, full dedication, and time. Trauma surgeons around the world have (happily) incorporated acute care surgery into their practice are becoming more proficient in minimally invasive surgery and utilize advanced imaging and IR technologies. Compared to the fellowship in trauma I did 25 years ago, current fellowships may offer training in IR, on advanced EVTM, and certainly will train the trauma fellow in critical care, organ/life support, and on a cacophony of monitors. The science of trauma has enormously evolved and quickly adapted 


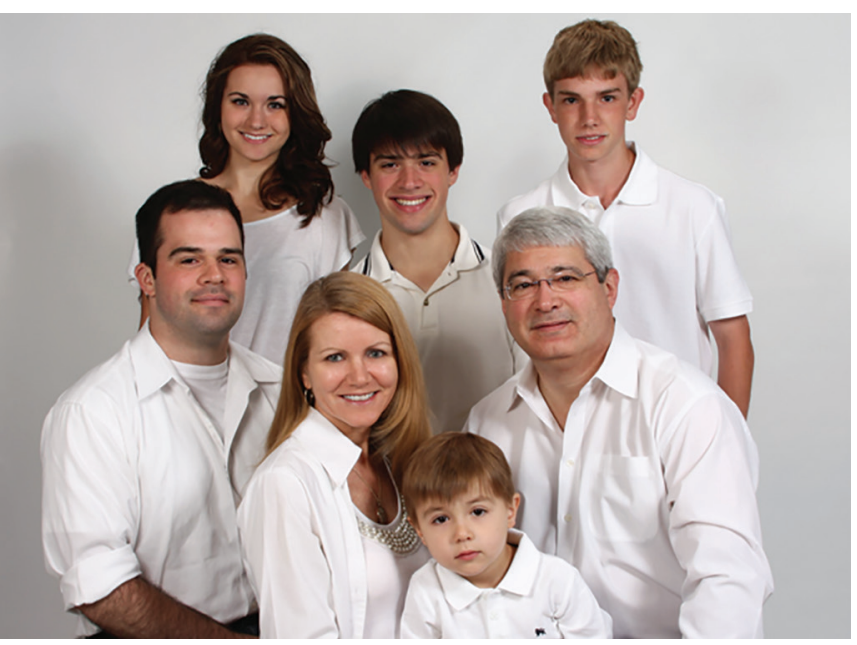

Fig. 1: Pacher-Rizoli family

to daily practice. The changes in IR, EVTM, multimodal monitors, etc., are not for the future but are present standards of care for many of us. We are living (and practicing) in a new world.

\section{The Most Important Advance = People}

Since the beginning trauma has been characterized by the work of teams. I am impressed with the fact that most presentations about the history of trauma are done using pictures of many people, nurses, residents, registrars, educators and so many other specialists. Very few pictures have a single person, most often it is a group photo.

Every injured patient goes through a continuum of care that initiated before the traumatic event occurred (injury prevention). Then care moves through pre-hospital teams, resuscitation in the trauma bay, operating room (OR), critical care (ICU), ward, and then rehabilitation. There is a team for every step, which integrates into the continuum of care to be functional. It is the trauma system where different institutions integrate care, teams in the trauma resuscitation, in the OR, ICU, ward, rehabilitation, etc.

Let me introduce you Kirsty Nixon and Heather Perry (Fig. 2), the faces of another extraordinary advance in patient care. Kirsty and Heather are nurse practitioners (NP) at SMH. They have independent licenses and scope of practice agreements. They round on all patients in trauma ward daily, write orders, discharge them, write them prescriptions, and arrange for follow up among many other things. They also run the NP trauma outpatient clinic where they start the visit by asking "how are you at home?". At their outpatient clinic, the patients are screened for mood disorders, post-traumatic stress disorder, head injury, pain, and substance abuse. They do everything and more. The addition of NP to the trauma team improved the quality of care and health outcomes. Example of their impact is the fact that around $80 \%$ of our outpatients used to get a prescription for narcotics for pain management. Because the NPs screen for disorders that are not treated with opioids (i.e., mood disorders, PTSD, etc.), we realized pain could be expressions of other maladjustments in response to trauma. Today, only $10 \%$ of the injured patients on the outpatient clinic need a prescription for opioids. The care we offer has improved. Because of the changes implemented by the NPs, other disorders are diagnosed and treated, many we were not diagnosing before. Other institutions such as Shock Trauma in Baltimore (also under the leadership of $\mathrm{Dr}$ Scalea) offer residency/fellowship programs for trauma NPs.

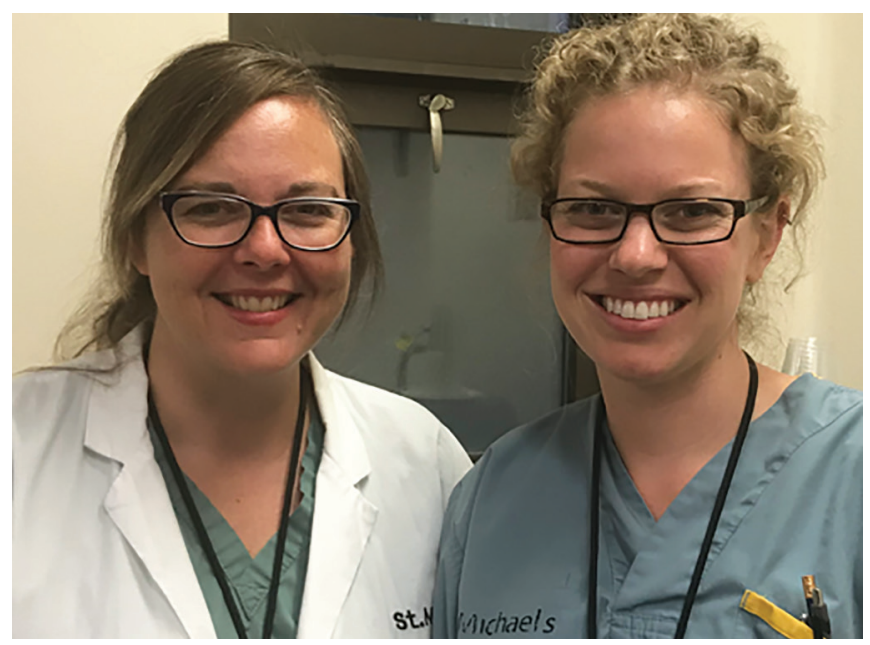

Fig. 2: Kirsty Nixon and Heather Perry, nurse practitioners of the St Michael's Hospital

Kirsty and Heather are examples of the growing role of nonsurgeons in trauma care. In my hospital, the NPs work along surgeons, residents, and fellows and are essential members of the group. It is important to mention case managers that assist with repatriation and discharges, dieticians, occupational therapists, physiotherapists, chaplains, and social workers, different professionals doing essential parts of the care and complementing each other for the benefit of the patients.

Examples of other key professionals to any trauma program are those involved in injury prevention programs, research, registry, and quality improvement (QI) programs. Our QI manager Amanda McFarlan, along with a trauma survivor Margaret Harvey, created and run the trauma survivor network. The My Best (beyond surviving - thriving) network provides support to survivors even years after hospital discharge. The care of injured patients does not end the moment they leave the hospital. In fact, for most it takes years (some may take their entire lives) to readjust to life after a major traumatic event. We like to think trauma professionals care for the entire patient, which is true, and the need for this approach comes from the fact that the entire life changes after major injury.

"To raise a child takes a village," the same can be said about caring for a single injured patient, it requires a "village" of many professionals. Surgeons like nurses, physiatrists, etc., are part of a team. The importance and role of different professionals in trauma care is evolving and growing. Each professional has a niche she/he is better qualified to do. In my opinion, people have had a larger impact in improving trauma care than science.

The goal in managing injured patients is the best and allinclusive outcomes possible. Patients are the reason for everything we do. We are learning how important each step in the care determine outcome. Every step and transitions count.

\section{Can Road Traffic and Gun Violence End? A Case for Justice}

While trauma care has evolved becoming more patient-centered and delivered by many professionals, our political world has not changed much. Every day, we continue to hear news of violence. Recent ones include NATO countries pushed to spend more on armaments, militarization of outer space, growing number of armed conflicts/wars, border closures, border walls, and refuges. 
Colombia itself has recently experienced the inflow of about 1.5 million displaced people leaving neighbor Venezuela.

The recent history of the Americas has also been marked by violence. Colombia war with the guerilla resulted in 260,000 deaths, Venezuela and Nicaragua are facing internal conflicts, mass shootings in the United States, over 6,000 homicides in Rio de Janeiro last year, and even in my home town of Toronto, we have seen a wave of violent incidents. Canada was stunned by a van driven into the sidewalk last April, in a terrorist attack that killed 10 people. Just 2 weeks ago, a person went on a shooting spree a few kilometers from my house, injuring 13 while news of violence in Fredericton plus the 2008 bombing of the Air India flight are still in our minds. These events are happening (literally) too close to home.

Injured patients succumb mostly of two causes: road traffic and gun violence, and both are preventable. I confess that I have been more focused in-hospital care than prevention, but the thought violence could be eradicated is very attractive. May be impossible in my life time? I am learning it is possible.

Many of you may be familiar with the concept of Vision Zero. It is an initiative to end deaths from road traffic events. I like to think gun violence could be added to this goal. For the last century, cities were built for cars. The proposal is to change and make cities for human life. Immediately I think such ideas would only suite European and a few socialist countries. But to my surprise I learned Vision Zero was adopted in New York City. Recently, NYC mayor announced that in 4 years, NYC experienced a 50\% drop in pedestrians' fatalities but instituting simple measures that consider peoples' lives more important than cars. I confess that I have heard nothing about Vision Zero in the news.

We treat patients suffering of a disease, trauma, which is mostly caused by road traffic and gun violence, and both are fully preventable. It is possible to eradicate them. No death by a preventable cause should be acceptable. On behalf of our patients, we should aim to see trauma end.

\section{The PTS}

The history and the past of the PTS were mentioned by Dr Scalea in the opening lecture of this Congress, while the full history can be found in Drs Ivatury and Aboutanos' paper in the Panamerican Journal of Trauma (PAJTCCES). ${ }^{2,3}$ The PTS is a society founded and nurtured by many present here today including Dr Aurelio Rodrigues, Dr Barba, and Dr Olguin. As Dr Ivatury once mentioned, the PTS is "built on the shoulder of giants."

Today, the PTS is going through a time of renovation and change. The Society exists to bring together all trauma professionals, from across the continent (speaking four languages: Spanish, Portuguese, English, and French), to work together toward improving care of the injured patient. The changes in the PTS can be witnessed in the restructuring of our annual congress. The 2018 Congress is a different proposition, from how it was planned with the ACC to how the lectures were delivered (Consensus conferences with open participation instead of lectures). Today we have the privilege of living this transformation in the beautiful city of Cartagena, which I confess was as a bait to attract participants.

The Society is also committed to increase the participation of women, non-surgeon professionals, to give opportunity and nurture emerging leaders and increase collaborations across borders by increasing opportunities to train overseas, exchange of trainees, multi-national teleconferences, guidance in how to write manuscripts, and the exemplary medical student's trauma leagues created by Drs Mantovani and Gustavo Fraga.

The transformation of the Panamerican Journal of Trauma Critical Care and Emergency Surgery (PAJTCCES) is a prime example of the recent changes in the Society, and of Dr Ivatury's decisive leadership. The expectation is for the Journal to be Pubmed indexed soon and continue to grow as a vehicle for the scientific production in the Americas.

Other major PTS initiatives include the success of numerous courses offered by the Society. Courses are among the best products created and offered by the PTS. The Society also sponsors multi-institutional trials to stimulate multi-national and multiinstitutional collaborations and take advantage of a strength of Latin American: volume of patients and outstanding trauma care. "Fresh out of the oven" is the new edition of the PTS Trauma book, a top publication of our Society. Dr Aurelio Rodriguez is the leading editor and Drs Ferrada, Ottolino, Aboutanos, Garcia, Lorenzo, Duschene, Pereira, and Parreira are associated editors. Finally, I want to extend my warm welcome to the new President Dr Felipe Vega from Mexico and Executive Secretary Dra Paula Ferrada. I also want to express great expectations for the 2019 Congress in La Serena in Chile.

\section{Conclusions}

I hope I was able to convey three messages. Trauma surgery has undergone tremendous changes over the last years. Major science and technology advances have been brought into our daily trauma activities and patient care. EVTM, ECMO, organ support, and multimodality monitoring are standard of care while trauma surgeons are now training in interventional radiology and acute care surgery. Despite the changes brought by the advances in science, trauma practice has changed because of the different professionals with growing roles in an ever-changing complex practice. The patients are the beneficiaries of all the changes in the process of care. Finally, the recognition that trauma is a preventable disease and it is possible to end it. No one should die or suffer from road traffic or gun violence.

It has been one of the best experiences in my life to be the President of the PTS. Its major asset, like in any trauma system, is the people we have the privilege of having as members, from all over the continent, that are pushing the boundaries of knowledge and care. Members that share a common vision: the best care to the injured patient.

Returning to the fictitious question my daughter could make me, what specialty I would advise her to follow, I would give two suggestions: 1 . be a trauma surgeon but more importantly; 2 . join the PTS. Thank you to the Asociacion Colombiana de Cirurgia, to Cartagena for its hospitality and to each member of the PTS for building this Society, Muchisimas gracias.

\section{References}

1. Chesnut RM, Temkin N, et al. A trial of intracranial-pressure monitoring in traumatic brain injury. N Engl J Med 2012 Dec 27;367(26):2471-2481. DOI: 10.1056/NEJMoa1207363.

2. Ivatury RR, Aboutanos M. Review article Panamerican Trauma Society: the first three decades. Panamerican J Trauma Crit Care Emerg Surg 2017 May-Aug;6(2):90-123.

3. Ivatury RR, Aboutanos M. Panamerican Trauma Society: the first three decades. J Trauma Acute Care Surg. 2017 May;82(5):966-973. DOI: 10.1097/TA.0000000000001393. 